\title{
вмJ Global Health COVID-19 as social disability: the opportunity of social empathy for empowerment
}

To cite: Ebuenyi ID,

Smith EM, Holloway C, et al. COVID-19 as social disability: the opportunity of social empathy for empowerment. BMJ Global Health

2020;5:e003039. doi:10.1136/ bmjgh-2020-003039

Handling editor Seye Abimbola

Received 29 May 2020

Revised 10 July 2020

Accepted 23 July 2020

Check for updates

(C) Author(s) (or their employer(s)) 2020. Re-use permitted under CC BY-NC. No commercial re-use. See rights and permissions. Published by BMJ.

${ }^{1}$ Assisting Living \& Learning (ALL) Institute, Department of Psychology, Maynooth University, Maynooth, Ireland ${ }^{2}$ Interaction Centre and Global Disability Innovation Hub, University College London, London, United Kingdom ${ }^{3}$ World Federation of the DeafBlind (WFDB), Oslo, Norway ${ }^{4}$ Olomouc University Social Health Institute (OUSHI), Palacký University, Olomouc, Czech Republic

Correspondence to Dr Ikenna D Ebuenyi; ikenna.ebuenyi@mu.ie
Social empathy is 'the ability to more deeply understand people by perceiving or experiencing their life situations and as a result gain insight into structural inequalities and disparities'. ${ }^{1}$ Social empathy comprises three elements: individual empathy, contextual understanding and social responsibility. ${ }^{1}$ COVID-19 has created a population-wide experience of exclusion that is only usually experienced by subgroups of the general population. ${ }^{2}$ Notably, persons with disability, in their everyday lives, commonly experience many of the phenomena that have only recently been experienced by members of the general population. Although about 1 billion people or approximately $15 \%$ of the world's population, have some form of disability, ignorance and fear about disability and discrimination towards people with disability still persists. ${ }^{3}$ Public understanding of disability is shaped by a medical model of individual deficit, ignoring societal barriers that transpose the attribute of some type of psychological or bodily impairment into the social experience of disability . ${ }^{4}$ This is the core message of the social model of disability that recognises the role of the social environment in the experience of disability. ${ }^{4}$

While there are many personal and social aspect of disability that people without a disability may never experience, there is an opportunity for the population-wide experience of COVID-19 to change others' perceptions of people with disability. The reported differential impact of COVID-19 on persons with disabilities highlights systemic barriers and their impact on those left behind by the social system. ${ }^{56}$ The conflating of disability with 'comorbidity' or 'frailty' is not due to any biological predilection for the virus but rather to implicit ableist assumptions that the 'elderly' or persons with pre-exiting 'conditions' are similar to people with disability. This

\section{Summary box}

COVID-19 has conferred new experiential knowledge on society and a rare opportunity to better understand the social model of disability and to improve the lives of persons with disabilities.

- The COVID-19 experience may offer contextual knowledge of the prepandemic lives of persons with disabilities and foster greater social awareness, responsibility and opportunities for change towards a more inclusive society.

- Information, family and social relationships, health protection and healthcare, education, transport and employment should be accessible for all groups of the population. The means must be developed and deployed to ensure equity - the deployment of resources so that people with different types of needs have the same opportunities for living good lives in inclusive communities.

- We have learnt from COVID-19 that inclusive healthcare and universal access should be the new normal, that its provision as a social good is both unifying and empowering for society as a whole.

also ignores the intersectionality of discrimination (gender, income, ethnicity and education) that compounds and heightens risk for persons with disability. ${ }^{46}$

The COVID-19 experience may offer contextual experience of the prepandemic lives of persons with disabilities and in doing so foster greater social responsibility and opportunities for change and a more inclusive society. In the following commentary, we highlight this by drawing parallels between articles of the United Nations Convention on the Rights of Persons with Disabilities (UNCRPD) ${ }^{7}$ about the COVID-19 experience and common experiences of people with disabilities.

Confinement, isolation, lack of connection and interaction with immediate surroundings and family is an aspect of the COVID-19 experience and is highlighted in Article 19 
(UNCRPD): 'Living independently and being included in the community'. The COVID-19 experience has given some a sense of what it must be like to live in institutions and not being able to 'get out', or living in a house in the community but still feeling apart from the local community. Isolation and loneliness are a common experience for some people with disability. ${ }^{6}$

Feeling well informed-having access to good information-has, for some, been a struggle in COVID-19 times. UNCRPD Article 21 concerns 'access to information"; due to the COVID-19 pandemic, the general population have experienced the challenges of receiving information that is not always clear or understandable ${ }^{56}$ This is similar to the everyday experience of some people with disabilities who have to contend with public health information that is rarely available in accessible formats (sign language, captioning, easy-to-read or braille documents).

There have also been reports of some people being made to feel 'different' because of their COVID-19 status. Article 5 of the UNCRPD relates to 'Equality and Non-Discrimination. ${ }^{7}$ The onset of COVID-19 has shown that people might be discriminated against based on nationality, age or other attributes because of the perceived predilection for COVID-19. ${ }^{89}$ The advent of COVID-19, may have created anxiety about contamination, and fearful reactions to and stigmatisation of those who are believed to have come in contact with it. ${ }^{9}$ This may even extend to the development of prejudice towards whole groups-Asian people ${ }^{8}$ - the vast majority of whom obviously have no association with COVID-19. The recent plan by the Chilean government to issue 'release certificates' to persons recovered from COVID-19 is another instance of use of illness as a divisive factor. ${ }^{10}$ This may be representative of the experience of legitimacy/illegitimacy experienced by some people with disability.

Access to healthcare for persons with or without COVID-19 has become difficult and is related to the Article 25 of the UNCRPD that describes 'right to health'. COVID-19 has led to prioritisation of people who receive healthcare services, with the concept of 'worth' attached to individuals, based on pre-existing health status, with cancelled, delayed or suspended services. ${ }^{6}{ }^{11} 12$ These challenges typify the barriers to accessing healthcare experienced by persons with disabilities, due to limited accessible services, poor understanding of individual needs, and lack of appropriate equipment. ${ }^{13}$

Reduced opportunities for or access to education, work and employment are the focus of Articles 24 and 27, respectively. ${ }^{7}$ The COVID-19 experience offers insights into the experience of loss of meaning, loss of opportunity to participate, loss of income, living on benefits but not being able to contribute, loss of identity as an independent and valued asset of the community and perhaps an inability to work or study remotely due to lack of accessibility. ${ }^{5}$ However, we now have a greater understanding as a society that alternative work and/or education formats are possible and are effective, which may result in increased chances for persons with disabilities and equalise opportunity in the future.

These few examples provide the general population an opportunity for social empathy and action to enhance social inclusion for people with disability. We offer the following recommendations to ensure that this moment of collective social insight is not squandered, repressed or simply forgotten as we rush back to 'normal':

- First, it obvious that being forced to stay indoors is not pleasant for anybody, nor is it socially acceptable for others to be lonely or isolated. It is important to promote varied mechanisms for interaction, inclusion and participation within and across our communities for persons with disabilities.

- Second, information should be accessible to all groups of the population, and alternative means of communication should be incorporated systematically to inform and enable all persons based on their own needs and abilities.

- Third, some population groups are more likely to experience discrimination and to be pushed into the corners of society. Social policies that promote equitythe distribution of resources so that people with different attributes have the same opportunities-in society will create a society for all.

- Fourth, we have learnt from COVID-19 that inclusive healthcare is desired by all, that it has the potential to weave us together and that no one should be denied access based on personal attributes. Universal healthcare should be the new normal not a privilege. ${ }^{14}$

- Finally, we now understand the socioeconomic experiences of vulnerable groups in settings where social welfare is absent. ${ }^{12} 15$ Social protection and benefits are among the measures recommended by the International Labour Organization to fight COVID-19. ${ }^{16}$ As we come out of COVID-19, it is important to recognise the purpose and meaning of engaging in work, for all, across all abilities. Alternative means of working and studying should allow for greater accessibility for everyone.

COVID-19 has conferred new experiential knowledge on all of us. We have a rare opportunity to understand and better the lives of persons with disabilities for whom some aspects of the COVID- 19 experience are enduring. This allows us greater understanding of the importance of implementing in full a social and human rights model of disability, as outlined in the UNCRPD. To not learn from history may well doom us to repeat it, but to not learn from our experience of the present, is to wilfully neglect the opportunities of the moment. As a society have we learnt that we are better than that?

Contributors All authors were involved in the conceptualisation and drafting of the manuscript.

Funding IDE and MM are funded by Irish Research Council grant (COALESCE/2019/114). EMS and CH are funded by Assistive Technology 2030, funded by UK AID and led by GDI Hub. EMS is funded in part by a Postdoctoral Fellowship from the Canadian Institutes of Health Research.

Competing interests None declared. 
Patient consent for publication Not required.

Provenance and peer review Not commissioned; externally peer reviewed.

Data availability statement There are no data in this work.

Open access This is an open access article distributed in accordance with the Creative Commons Attribution Non Commercial (CC BY-NC 4.0) license, which permits others to distribute, remix, adapt, build upon this work non-commercially, and license their derivative works on different terms, provided the original work is properly cited, appropriate credit is given, any changes made indicated, and the use is non-commercial. See: http://creativecommons.org/licenses/by-nc/4.0/.

\section{ORCID iDs}

Ikenna D Ebuenyi http://orcid.org/0000-0002-3329-6296

Emma M Smith http://orcid.org/0000-0003-2541-5723

Malcolm MacLachlan http://orcid.org/0000-0001-6672-9206

\section{REFERENCES}

1 Segal EA. Social empathy: a model built on empathy, contextual understanding, and social responsibility that promotes social justice. J Soc Serv Res 2011;37:266-77.

2 Armitage R, Nellums LB. The COVID-19 response must be disability inclusive. Lancet Public Health 2020;5:e257.

3 World Health Organization. WHO global disability action plan 2014-2021: better health for all people with disability. World Health Organization, 2015.

4 Watson N, Vehmas S. Routledge handbook of disability studies. Routledge, 2019.

5 Pineda VS, Corburn J, Disability CJ. Disability, urban health equity, and the coronavirus pandemic: promoting cities for all. J Urban Health 2020;97:336-41.
6 Thelwall M, Levitt JM. Retweeting Covid-19 disability issues: risks, support and outrage, 2020.

7 United Nations. Convention on the rights of persons with disabilities (CRPD), 2006. Available: https://www.un.org/development/desa/ disabilities/convention-on-the-rights-of-persons-with-disabilities. html

8 Moukaddam N, Shah A. Psychiatrists beware! the impact of COVID-19 and pandemics on mental health. 37. Psychiatric Times, 2020.

9 Shigemura J, Ursano RJ, Morganstein JC, et al. Public responses to the novel 2019 coronavirus (2019-nCoV) in Japan: mental health consequences and target populations. Psychiatry Clin Neurosci 2020;74:281-2

10 Fraser B. Chile plans controversial COVID-19 certificates. Lancet 2020;395:1473.

11 Prvu Bettger J, Thoumi A, Marquevich V, et al. COVID-19: maintaining essential rehabilitation services across the care continuum. BMJ Glob Health 2020;5:e002670.

12 Kavanagh MM, Erondu NA, Tomori O, et al. Access to lifesaving medical resources for African countries: COVID-19 testing and response, ethics, and politics. Lancet 2020;395:1735-8.

13 Munthali AC, Swartz L, Mannan H, et al. "This one will delay us": barriers to accessing health care services among persons with disabilities in Malawi. Disabil Rehabil 2019;41:683-90.

14 Mannan H, MacLachlan M. Disability and health: a research agenda, 2013.

15 Ebuenyi ID. COVID-19: an opportunity for African governments to rethink social welfare benefits and protection. Pan Afr Med J 2020;35.

16 International Labour Organisation. COVID-19: protecting workers in the workplace, 2020. Available: https://www.ilo.org/global/aboutthe-ilo/newsroom/news/WCMS_738742/lang-en/index.htm 